\title{
Anatomical and molecular characterization of dopamine D1 receptor-expressing neurons of the mouse CA1 dorsal hippocampus
}

\author{
Emma Puighermanal ${ }^{1,2,3} \cdot$ Laura Cutando ${ }^{1,2,3} \cdot$ Jihane Boubaker-Vitre $^{1,2,3}$. \\ Eve Honoré ${ }^{1,2,3} \cdot$ Sophie Longueville ${ }^{4,5,6} \cdot$ Denis Hervé $\dot{e}^{4,5,6} \cdot$ Emmanuel Valjent $^{1,2,3}$
}

Received: 2 August 2016/Accepted: 15 September 2016/Published online: 27 September 2016

(C) The Author(s) 2016. This article is published with open access at Springerlink.com

\begin{abstract}
In the hippocampus, a functional role of dopamine D1 receptors (D1R) in synaptic plasticity and memory processes has been suggested by electrophysiological and pharmacological studies. However, comprehension of their function remains elusive due to the lack of knowledge on the precise localization of D1R expression among the diversity of interneuron populations. Using BAC transgenic mice expressing enhanced green fluorescent protein under the control of D1R promoter, we examined the molecular identity of D1R-containing neurons within the CA1 subfield of the dorsal hippocampus. In agreement with previous findings, our analysis revealed that these neurons are essentially GABAergic interneurons, which express several neurochemical markers, including calcium-binding proteins, neuropeptides, and receptors among others. Finally, by using different tools comprising cell typespecific isolation of mRNAs bound to tagged-ribosomes, we provide solid data indicating that D1R is present in a
\end{abstract}

Electronic supplementary material The online version of this article (doi:10.1007/s00429-016-1314-x) contains supplementary material, which is available to authorized users.

Emmanuel Valjent

emmanuel.valjent@igf.cnrs.fr;

emmanuel.valjent@gmail.com

1 CNRS UMR 5203, Institut de Génomique Fonctionnelle, 141 rue de la Cardonille, 34094 Montpellier Cedex 05, France

2 INSERM, U1191, Montpellier 34094, France

3 Université de Montpellier, UMR 5203, Montpellier 34094, France

4 Inserm, UMR-S 839, 75005 Paris, France

5 Université Pierre et Marie Curie-Paris 6, 75005 Paris, France

6 Institut du Fer à Moulin, 75005 Paris, France large proportion of interneurons expressing dopamine D2 receptors. Altogether, our study indicates that D1Rs are expressed by different classes of interneurons in all layers examined and not by pyramidal cells, suggesting that CA1 D1R mostly acts via modulation of GABAergic interneurons.

Keywords Dopamine D1 receptor - BAC transgenic mice . Interneurons $\cdot$ Hippocampus $\cdot$ RiboTag mice

$\begin{array}{ll}\text { Abbreviations } \\ \text { Cx } & \text { Cortex } \\ \text { DG } & \text { Dentate gyrus } \\ \text { cc } & \text { Corpus callosum } \\ \text { s.o. } & \text { Stratum oriens } \\ \text { s.p. } & \text { Stratum pyramidale } \\ \text { s.r. } & \text { Stratum radiatum } \\ \text { s.l. } & \text { Stratum lucidum } \\ \text { s.l.-m. } & \text { Stratum lacunosum-moleculare } \\ \text { s.m. } & \text { Stratum moleculare } \\ \text { o-s.m. } & \text { Outer two thirds of the stratum moleculare } \\ \text { i-s.m. } & \text { Inner-third of the stratum moleculare } \\ \text { s.gr. } & \text { Stratum granulosum } \\ \text { h } & \text { Hilus } \\ \text { EGFP } & \text { Enhanced green fluorescent protein } \\ \text { HA } & \text { Hemagglutinin } \\ \text { CB } & \text { Calbindin-D28k } \\ \text { CR } & \text { Calretinin } \\ \text { PV } & \text { Parvalbumin } \\ \text { NPY } & \text { Neuropeptide Y } \\ \text { SOM } & \text { Somatostatin } \\ \text { nNOS } & \text { Neuronal nitric oxide synthase } \\ \text { RLN } & \text { Reelin } \\ \text { VGLUT3 } & \text { Vesicular glutamate transporter type } 3 \\ \text { D1R } & \text { Dopamine D1 receptor } \\ \end{array}$


D2R Dopamine D2 receptor

CB1R Cannabinoid type 1 receptor

mGluR1 $\alpha$ Metabotropic glutamate receptor type $1 \alpha$

\section{Introduction}

Beside its crucial role in encoding reward-related events (Schultz 2016), dopamine (DA) also processes salient/nonrewarding signals (Bromberg-Martin et al. 2010). This functional diversity is underlined by the molecular, electrophysiological, and projection-specific heterogeneity of midbrain DA neurons (Lammel et al. 2012; Poulin et al. 2014). For instance, the activation of DA neurons projecting to the lateral shell of the nucleus accumbens triggers reward-associated behaviors while those innervating the medial prefrontal cortex control aversion (Lammel et al. 2012; Poulin et al. 2014). The optimal processing of both rewarding and aversive events also relies on the ability of properly using contextual information (Lisman and Grace 2005). In this context, numerous evidence indicate that midbrain DA neurons projecting to the dorsal hippocampus are activated when animals are exposed to novel environment (Horvitz et al., 1997; Ljungberg et al., 1992), thereby facilitating the encoding of novel contextual cues associated with rewards or potential threats (Bromberg-Martin et al. 2010).

Tract-tracing studies indicate that in the dorsal hippocampus DA neurons originating from the ventral tegmental area (VTA) preferentially innervate CA1 subfields (Broussard et al. 2016; Gasbarri et al. 1997; McNamara et al. 2014; Rosen et al. 2015). Within this area, DA through the stimulation of D1-like receptors has been shown to regulate aversive contextual learning (Broussard et al. 2016; Furini et al. 2014; Heath et al. 2015; Rossato et al. 2009), object-place configuration learning (Furini et al. 2014; Lemon and Manahan-Vaughan 2006) and strength new spatial memories (Bethus et al. 2010; McNamara et al. 2014).

The localization of D1R in the CA1 subfield has been for a long time elusive. Drdla-EGFP BAC transgenic mice represent a valuable tool to address this issue (Valjent et al. 2009). The analysis of GFP-positive cells indicates that D1R-expressing neurons populate all CA1 layers and express GAD67, a marker of GABAergic interneurons (Gangarossa et al., 2012). However, the identity of D1Rexpressing CA1 GABAergic interneurons among the thirty-seven distinct types identified remains unknown (Wheeler et al. 2015; http://www.hippocampome.org). We therefore conducted a careful examination of the molecular identity of GFP-expressing neurons in the CA1 subfield of Drdla-EGFP mice.

\section{Materials and methods}

\section{Mouse mutants}

Male and female, 8-12-week old, Drdla-EGFP $(n=11$ C57BL/6N background, founder S118), Drd2-Cre (C57BL/ $6 \mathrm{~J}$ background, founder ER44) heterozygous mice and RiboTag:loxP [The Jackson Laboratory, (Sanz et al., 2009)] were used in this study. BAC Drdla-EGFP and Drd2-Cre mice were generated by GENSAT (Gene Expression Nervous System Atlas) at the Rockefeller University (New York, NY, USA) (Gong et al. 2003). Homozygous RiboTag female mice were crossed with heterozygous Drd2-Cre male mice to generate Drd2Cre::RiboTag mice (Puighermanal et al., 2015). Animals were maintained in a 12 hour light/dark cycle, in stable conditions of temperature and humidity, with food and water ad libitum. All experiments were in accordance with the guidelines of the French Agriculture and Forestry Ministry for handling animals (authorization number/license D34-172-13).

\section{Tissue preparation and immunofluorescence}

Mice were rapidly anaesthetized with pentobarbital (500 mg/kg, i.p., Sanofi-Aventis, France) and transcardially perfused with $4 \%$ (weight/vol.) paraformaldehyde in $0.1 \mathrm{M}$ sodium phosphate buffer ( $\mathrm{pH}$ 7.5) (BertranGonzalez et al. 2008). Brains were post-fixed overnight in the same solution and stored at $4{ }^{\circ} \mathrm{C}$. Thirty- $\mu \mathrm{m}$ thick sections were cut with a vibratome (Leica, France) and stored at $-20{ }^{\circ} \mathrm{C}$ in a solution containing $30 \%$ (vol/vol) ethylene glycol, $30 \%$ ( vol/vol) glycerol, and $0.1 \mathrm{M}$ sodium phosphate buffer, until they were processed for immunofluorescence. Hippocampal sections were identified using a mouse brain atlas and sections comprised between -1.34 and $-2.06 \mathrm{~mm}$ from bregma were included in the analysis (Franklin and Paxinos 2007). Sections were processed as follows: free-floating sections were rinsed three times 10 minutes in Tris-buffered saline $(50 \mathrm{mM}$ Tris-HCL, $150 \mathrm{mM} \mathrm{NaCl}$, pH 7.5). After 15 minutes incubation in $0.2 \%(\mathrm{vol} / \mathrm{vol})$ Triton $\mathrm{X}-100$ in TBS, sections were rinsed in TBS again and blocked for 1 hour in a solution of $3 \%$ BSA in TBS. Finally, they were incubated 72 hours at $4{ }^{\circ} \mathrm{C}$ in $1 \%$ BSA, $0.15 \%$ Triton X-100 with the primary antibodies (Table 1 ). Sections were rinsed three times for 10 minutes in TBS and incubated for 45-60 minutes with goat Cy2-, Cy3- and Cy5-coupled (1:400, Jackson Immunoresearch) and/or goat alexafluor 488 (1:400, Life Technologies). Sections were rinsed for 10 minutes twice in TBS and twice in Tris-buffer $(1 \mathrm{M}, \mathrm{pH}$ 
Table 1 List of primary antibodies

\begin{tabular}{lllll}
\hline Antigen & Host & Dilution & Supplier & Catalog no \\
\hline HA & Mouse & $1: 1000$ & Covance & MMS-101R \\
GFP & Chicken & $1: 1000$ & Life Technologies & A10262 \\
CR & Rabbit & $1: 1000$ & Swant & $7699 / 3 \mathrm{H}$ \\
CB & Rabbit & $1: 1000$ & Swant & CB382 \\
PV & Rabbit & $1: 1000$ & Swant & PV25 \\
mGluR1 $\alpha$ & Rabbit & $1: 500$ & Abnova & PAB14526 \\
NPY & Rabbit & $1: 500$ & Abcam & ab10980 \\
SOM & Rabbit & $1: 300$ & Millipore & AB5494 \\
nNOS & Mouse & $1: 300$ & Sigma & N2280 \\
RLN & Mouse & $1: 500$ & Millipore & MAB5364 \\
VGLUT3 & Guinea pig & $1: 500$ & & Gift from El Mestikawy \\
CB1R & Rabbit & $1: 1000$ & Frontier Institute & CB1-Rb-Af380 \\
D2R & Rabbit & $1: 500$ & Frontier Institute & D2R-Rb-Af960 \\
\hline
\end{tabular}

$H A$ hemagglutinin, $G F P$ green fluorescent protein, $P V$ parvalbumin, $C B$ calbindin-D28k, $C R$ calretinin, $N P Y$ neuropeptide Y, $m G l u R l \alpha$ metabotropic glutamate receptor type $1 \alpha$, SOM somatostatin, $n N O S$ neuronal nitric oxide synthase, $R L N$ reelin, VGLUT3 vesicular glutamate transporter type 3,CB1R cannabinoid receptor type $1, D 2 R$ dopamine D2 receptor
7.5) before mounting in 1,4-diazabicyclo-[2. 2. 2]-octane (DABCO, Sigma-Aldrich).

Confocal microscopy and image analysis were carried out at the Montpellier RIO Imaging Facility. Images covering the entire dorsal hippocampus were single confocal sections acquired using sequential laser scanning confocal microscopy (Zeiss LSM780). Double-labeled images from each region of interest were single section obtained using sequential laser scanning confocal microscopy (Zeiss LSM780). Photomicrographs were obtained with the following band-pass and long-pass filter setting: alexafluor 488/Cy2 (band pass filter: 505-530), Cy3 (band pass filter: 560-615) and Cy5 (long-pass filter 650). Figure 1, 2, 3, 4, and 5: GFP labeled neurons were pseudocolored cyan and markers immunoreactive neurons were pseudocolored magenta. From the overlap of cyan and magenta, double-labeled neurons appeared white. Figure 4: GFP- and VGLUT3-labeled neurons were pseudocolored cyan and magenta and CB1R-positives fibers were pseudocolored yellow. Images used for quantification were all single confocal sections. GFP- and markers-positive cells were manually counted in the CA1 area taking into account the laminar location. Cells were considered positive for a given marker only when the nucleus was clearly visible. Adjacent serial sections were never counted for the same marker to avoid any potential double counting of hemisected neurons. Values in the histograms in Figures represent the co-expression as percentage of GFP-positive cells (darkened color) and as percentage of cells expressing the various markers tested in each laminar location in the CA1 subfield (6-12 hemispheres, $n=3-4$ mice). Total numbers of GFP- and marker-positive cells counted are reported in Table 2.

\section{Polyribosome immunoprecipitation}

HA-tagged-ribosome immunoprecipitation was performed as described previously (Sanz et al. 2009) with slight modifications. The hippocampus from Drd2-Cre::RiboTag mice was homogenized by douncing in 1-ml polysome buffer (50 mM Tris, pH 7.4, $100 \mathrm{mM} \mathrm{KCl,} 12 \mathrm{mM} \mathrm{MgCl}$, and $1 \% \mathrm{NP}-40$ supplemented with $1 \mathrm{mM}$ DTT, $1 \mathrm{mg} / \mathrm{ml}$

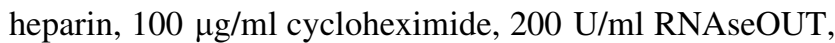
and protease inhibitor mixture). Samples were then centrifuged at $10,000 \times g$ for 10 minutes to collect the postmitochondrial supernatant. Then, $100 \mu \mathrm{l}$ of each supernatant was transferred to a new tube serving as input fraction for validation. Anti-HA antibody ( $5 \mu \mathrm{l} / \mathrm{sample}$; Covance, \#MMS-101R) was added to the remaining supernatant and incubated overnight at $4{ }^{\circ} \mathrm{C}$ with constant gently rotation. The following day, samples were added to protein G magnetic beads (Invitrogen, \#100.04D) and incubated overnight at $4{ }^{\circ} \mathrm{C}$ with constant gently rotation. On the third day, magnetic beads were washed twice in a magnetic rack for 10 minutes each in high-salt buffer (50 mM Tris, $\mathrm{pH} 7.4,300 \mathrm{mM} \mathrm{KCl}, 12 \mathrm{mM} \mathrm{MgCl}$, $1 \% \mathrm{NP}-40,1 \mathrm{mM}$ DTT, and $100 \mu \mathrm{g} / \mathrm{ml}$ cycloheximide). After washing, $350 \mu \mathrm{l}$ of Qiagen RLT buffer (supplemented with $\beta$-Mercaptoethanol) were added to the pellets and to the input samples. RNA was extracted according to manufacturer's instructions using a Qiagen RNeasy Micro kit and quantified using Nanodrop 1000 spectrophotometer.

\section{cDNA synthesis and quantitative real-time PCR}

Synthesis of cDNA was performed on input fraction $(10 \%$ of homogenate) and pellet fraction (after HA 
Fig. 1 Parvalbumin-, calbindin-D28k-, and calretininpositive neurons in the dorsal hippocampus in Drdla-EGFP mice. a, c, e Single immunofluorescence for GFP (left panels) and double immunofluorescence (right panels) for GFP (cyan) and parvalbumin (magenta, PV) (a), calbindin-D28k (magenta, CB)

(c), and calretinin (magenta, CR) (e) in CA1 dorsal hippocampus of Drdla-EGFP mice. a, c, e Yellow arrowheads indicate GFP/markers-positive neurons. b, d, f Histograms showing the co-expression as percentage of GFP-positive cells (darkened color, $\mathrm{GFP}^{+}$) and as percentage of cells expressing parvalbumin (lightened color, $\left.\mathrm{PV}^{+}\right)(\mathbf{b})$, calbindin-D28k (lightened color, $\left.\mathrm{CB}^{+}\right)(\mathbf{d})$, and calretinin (lightened color, $\mathrm{CR}^{+}$) (f). Numbers of $\mathrm{GFP}^{+}, \mathrm{PV}^{+}, \mathrm{CB}^{+}$ and $\mathrm{CR}^{+}$cells counted are reported in Table 2 (4 hemispheres per mouse, 4 mice). Scale bar $50 \mu \mathrm{m}$
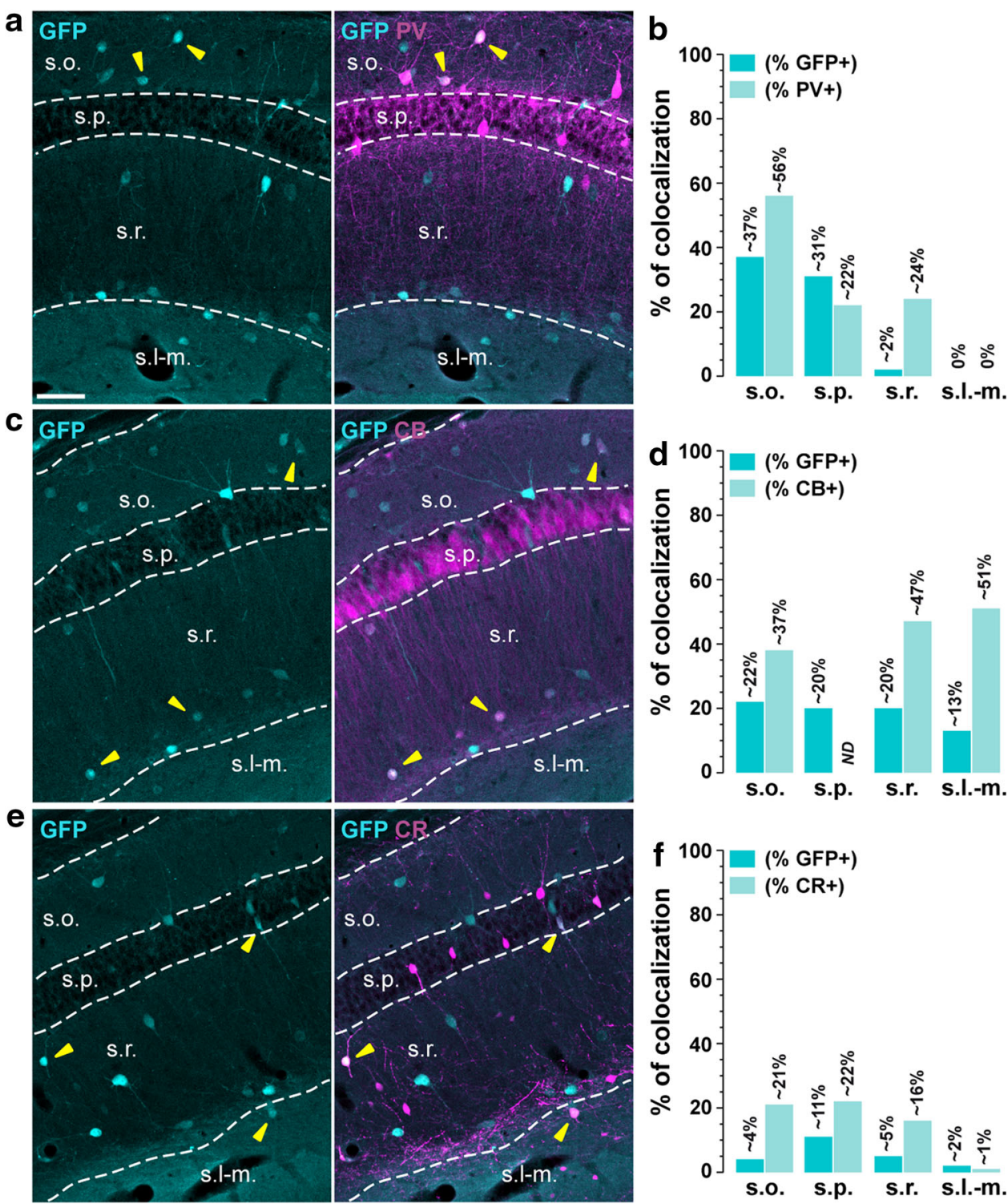

immunoprecipitation), which were reverse transcribed to first strand cDNA using the SuperScript ${ }^{\circledR}$ VILO $^{\text {TM }}$ cDNA synthesis kit (Invitrogen). Resulting cDNA was used for quantitative real-time PCR (qRT-PCR), using SYBR Green PCR master mix on the LC480 Real-Time PCR System (Roche) and the primer sequences listed in Table 3. Analysis was performed using LightCycler ${ }^{\circledR} 480$ Software (Roche). Data are expressed as the fold change comparing the pellet fraction versus the input ( 3 biological replicates per set of primers). The immunoprecipitated RNA samples (pellet) were compared to the input sample in each case.

\section{Statistical analysis}

Unpaired Student's $t$-test was used to compare changes in gene expression between inputs and pellets. Significance threshold was set at $p<0.05$. Prism 6.0 software was used to perform statistical analyses.

\section{Results}

\section{Distribution of D1R-expressing cells among calcium- binding proteins}

Parvalbumin (PV). PV-positive cells are widely distributed in the CA1 subfield (Fig. 1a). Depending on their location in the different layers they allow the classification of various GABAergic inhibitory interneurons (Klausberger 2009; Pawelzik et al. 2002). Thus, PV-expressing cells identified axo-axonic, basket, and bistratified interneurons in both strata pyramidale and oriens. In this latter layer, it 


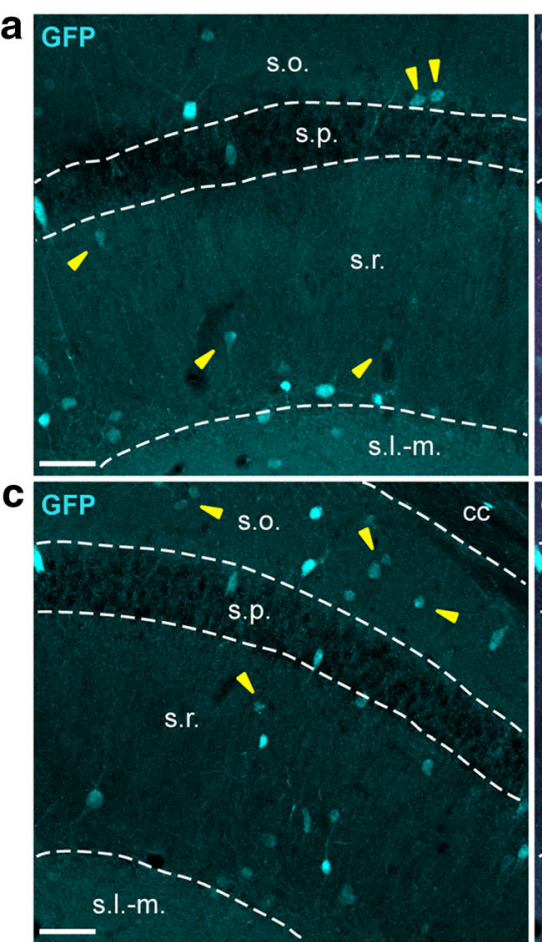

Fig. 2 Neuropeptide $\mathrm{Y}$ - and somatostatin-expressing cells in the dorsal hippocampus in Drdla-EGFP mice. a, c Single immunofluorescence for GFP (left panels) and double immunofluorescence (right panels) for GFP (cyan) and neuropeptide Y (magenta, NPY) (a) and somatostatin (magenta, SOM) (c) in dorsal hippocampus of Drdla-EGFP mice. a, c Yellow arrowheads indicate GFP/NPY- or

also marked the horizontal axo-axonic and oriens-lacunosum-moleculare (O-LM). Our analysis revealed that GFP/ PV-positive cells represented $\sim 37$ and $\sim 31 \%$ of the total GFP labeled in strata oriens and pyramidale, respectively (Fig. 1a, b; Table 2). Low or no co-localization was found in strata radiatum $(\sim 2 \%)$ and lacunosum-moleculare $(0 \%)$ where PV-positive cells identified perforant pathassociated QuadD, quadrilaminar, and R-receiving apical targeting interneurons (Fig. 1a, b; Table 2).

Calbindin-D28k $(C B)$. In CA1 subfield, CB-immunoreactivity is found in both principal glutamatergic cells in strata pyramidale and radiatum as well as in GABAergic interneurons located in strata oriens, radiatum, and lacunosum-moleculare (Jinno and Kosaka 2002) (Fig. 1c). In stratum pyramidale, we found that among the 272 GFPimmunoreactive cells quantified, 55 co-localized with CB ( $\sim 20 \%$ of total of GFP-positive neurons) (Fig. 1c, d; Table 2). In stratum oriens, where CB-positive cells identified recurrent O-LM, oriens alveus, and SO-SO cells, $\sim 22 \%$ of GFP-labeled neurons co-expressed CB (Fig. 1c, d). Finally, CB immunolabeling also marked LMR-projecting, radiatum, and Schaffer collateral associated classes of interneurons in strata radiatum and lacunosum-moleculare, in which $\sim 20$ and $\sim 13 \%$ of CB/GFP-positive neurons were detected (Fig. 1c, d; Table 2).

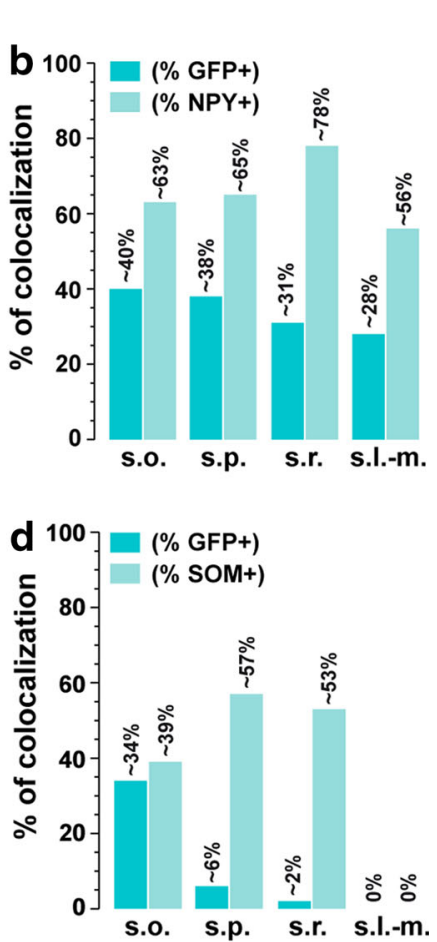

GFP/SOM-positive neurons. b, d Histograms showing the coexpression as percentage of GFP-positive cells (darkened color, $\mathrm{GFP}^{+}$) and as percentage of cells expressing NPY (lightened color, $\mathrm{NPY}^{+}$) (b) and somatostatin (lightened color, $\mathrm{SOM}^{+}$) (d). Numbers of $\mathrm{GFP}^{+}, \mathrm{NPY}^{+}$and $\mathrm{SOM}^{+}$cells counted are reported in Table 2 (4 hemispheres per mouse, 4 mice). Scale bars a, c, $50 \mu \mathrm{m}$

Calretinin $(C R)$. CA1 CR-positive cells are distributed in all the layers where they allow the identification of several classes of interneurons (Wheeler et al. 2015) (Fig. 1e). Overall, our analysis revealed a low degree of colocalization between GFP and CR immunoreactivity whatever the layers analyzed. The highest percentage of co-localization was found in stratum pyramidale $(\sim 11 \%)$ where CR-positive cells marked interneuron specific LMO$\mathrm{O}$, interneuron specific O-targeting QuadD, interneuron specific R-O, and interneuron RO-O, a class of interneurons specialized in the control of other interneurons (Fig. 1e, f; Table 2). In addition to interneurons specific, CR-positive cells were expressed in oriens-bistratified in stratum oriens and perforant path-associated QuadD, quadrilaminar, and Schaffer collateral receiving R-targeting cells in stratum radiatum. In both layers, GFP-positive cells expressing $\mathrm{CR}$ was rather low, representing only $\sim 4 \%$ in stratum oriens and $\sim 5 \%$ in stratum radiatum (Fig. 1e, f; Table 2). Finally, in stratum lacunosummoleculare where CR cells stain Cajal-Retzius cells and quadrilaminar interneurons, only three GFP/CR-positive cells were detected among the 173 GFP-immunoreactive cells (Fig. 1e, f; Table 2). These co-labeled cells which most likely correspond to quadrilaminar interneurons represented only $\sim 2 \%$ (Fig. 1e, f; Table 2 ). 

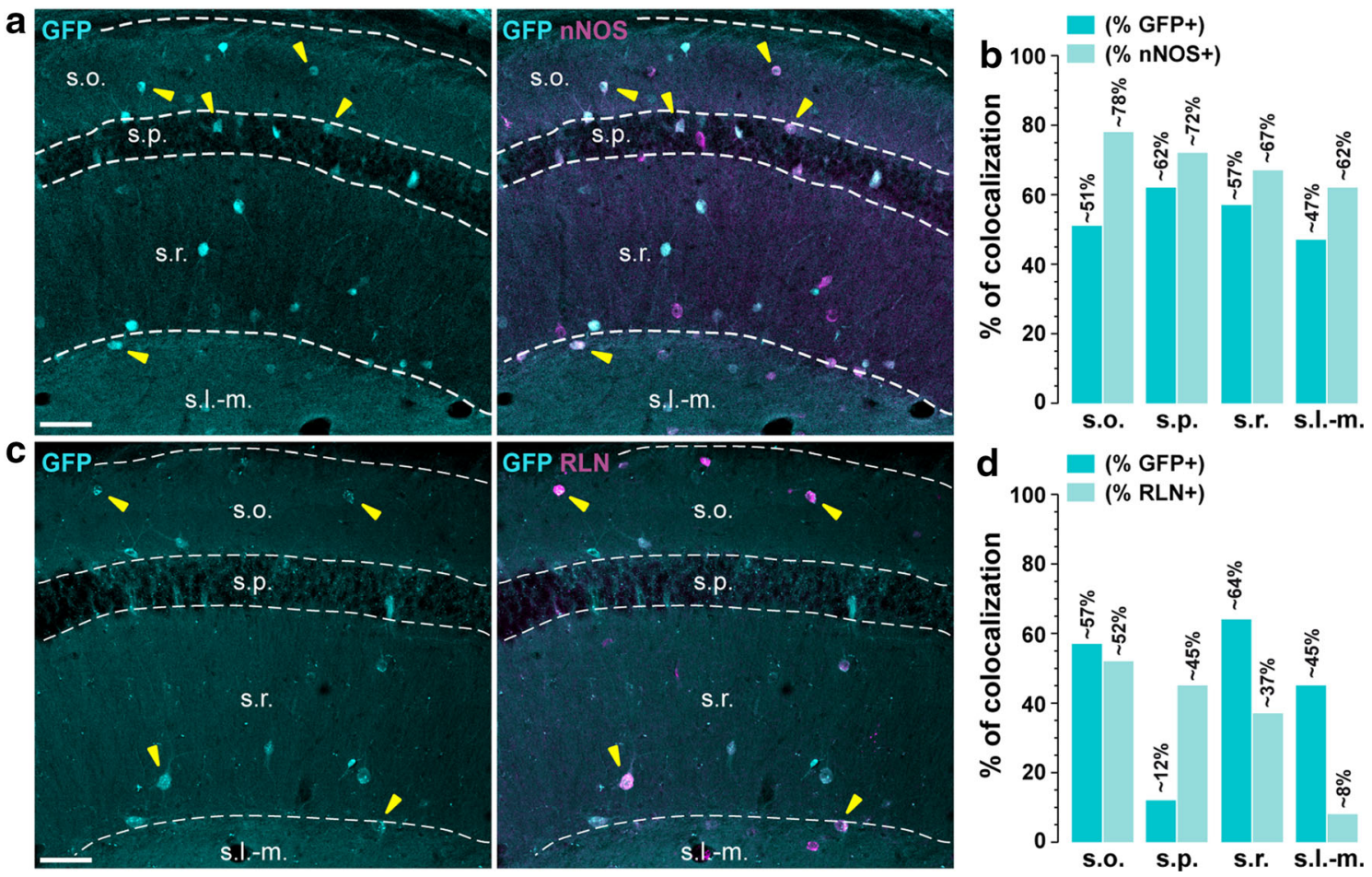

Fig. 3 Distribution of D1R-expressing cells among nNOS- and Reelin-positive neurons. a, c Single immunofluorescence for GFP (left panels) and double immunofluorescence (right panels) for GFP (cyan) and neuronal nitric oxide synthase (magenta, nNOS) (a) and reelin (magenta, RLN) (b) in dorsal hippocampus of Drdla-EGFP mice. a, c Yellow arrowheads indicate GFP/nNOS- or GFP/RLN-

\section{Distribution of D1R-expressing cells among neuropeptides}

Neuropeptide $Y(N P Y)$. NPY/GFP-positive neurons were found in all the layers of the CA1 subfield (Tricoire et al. 2011). Co-localized GFP and NPY immunoreactive cells represented $\sim 40 \%$ and of $\sim 38 \%$ of GFP-positive cells in strata oriens and pyramidale, respectively. Within these two layers, NPY marked back-projection, O-LM, recurrent O-LM, SO-SO interneurons as well as bistratified and ivy cells (Fig. 2a, b; Table 2). Co-localization was also high in strata radiatum $(\sim 31 \%)$ and lacunosum-moleculare $(\sim 28 \%)$ in which ivy, LMR, perforant path-associated QuaD, radiatum, and radial trilaminar interneurons as well as neurogliaform interneurons are distributed (Fig. 2a, b; Table 2).

Somatostatin $(S O M)$. The highest percentage of GFP/ SOM-positive neurons was detected in stratum oriens $(\sim 34 \%)$ where SOM is expressed by several classes of interneurons including O-LM, recurrent O-LM, O-LMR, oriens-bistratified, oriens-bistratified projecting as well as trilaminar (Chittajallu et al. 2013; Tricoire et al. 2011) (Fig. 2c, d; Table 2). In stratum pyramidale, only $\sim 6 \%$ of GFP-positive cells co-expressed SOM, a marker of positive neurons. b, d Histograms showing the co-expression as percentage of GFP-positive cells (darkened color, $\mathrm{GFP}^{+}$) and as percentage of cells expressing nNOS (lightened color, $\mathrm{nNOS}^{+}$) (b) and reelin (lightened color, $\mathrm{RLN}^{+}$) (d). Numbers of $\mathrm{GFP}^{+}$, nNOS $^{+}$and $\mathrm{RLN}^{+}$cells counted are reported in Table 2 (4 hemispheres per mouse, 3 mice). Scale bars a, c, $50 \mu \mathrm{m}$

Fig. 4 Distribution of D1R-expressing cells among mGluR1 $\alpha-$, CB1R, and VGLUT3-positive neurons. a GFP (cyan) and mGluR1 $\alpha$ (magenta) immunofluorescence in the dorsal hippocampus of DrdlaEGFP mice. Yellow arrowheads indicate GFP/mGluR $1 \alpha$-positive neurons in CA1 subfield Scale bar $50 \mu \mathrm{m}$. b Histograms showing the co-expression as percentage of GFP-positive cells (darkened color) and as percentage of cells expressing mGluR1 $\alpha$ (lightened color). Numbers of $\mathrm{GFP}^{+}$and mGluR1 $\alpha^{+}$cells counted are reported in Table 2 (4 hemispheres per mouse, 4 mice). c Triple immunofluorescence for GFP (cyan), the vesicular glutamate transporter type 3 (magenta, VGLUT3), and the cannabinoid receptor type 1 (yellow, CB1R) in the dorsal hippocampus of Drdla-EGFP mice. Scale bar $400 \mu \mathrm{m}$. d, e High magnification images of areas delineated by the yellow stippled squares. Red arrowheads indicate GFP/VGLUT3/ CB1R-positive neurons in the strata radiatum (d) and pyramidale (e) in CA1 subfield. Scale bars d, e, $60 \mu \mathrm{m}$

bistratified interneurons. It should be noted that a significant fraction $(\sim 57 \%)$ of these neurons appeared to express D1R. Finally, in strata radiatum where SOMcontaining cells identify LMR, perforant path-associated QuaD, quadrilaminar and radiatum interneurons, GFP/ SOM co-expressing cells represented only $\sim 2 \%$ of GFPpositive cells, but $53 \%$ of SOM-positive neurons (Fig. 2c, d; Table 2). No co-labeling was found in stratum lacunosum-moleculare (Fig. 2d; Table 2). 

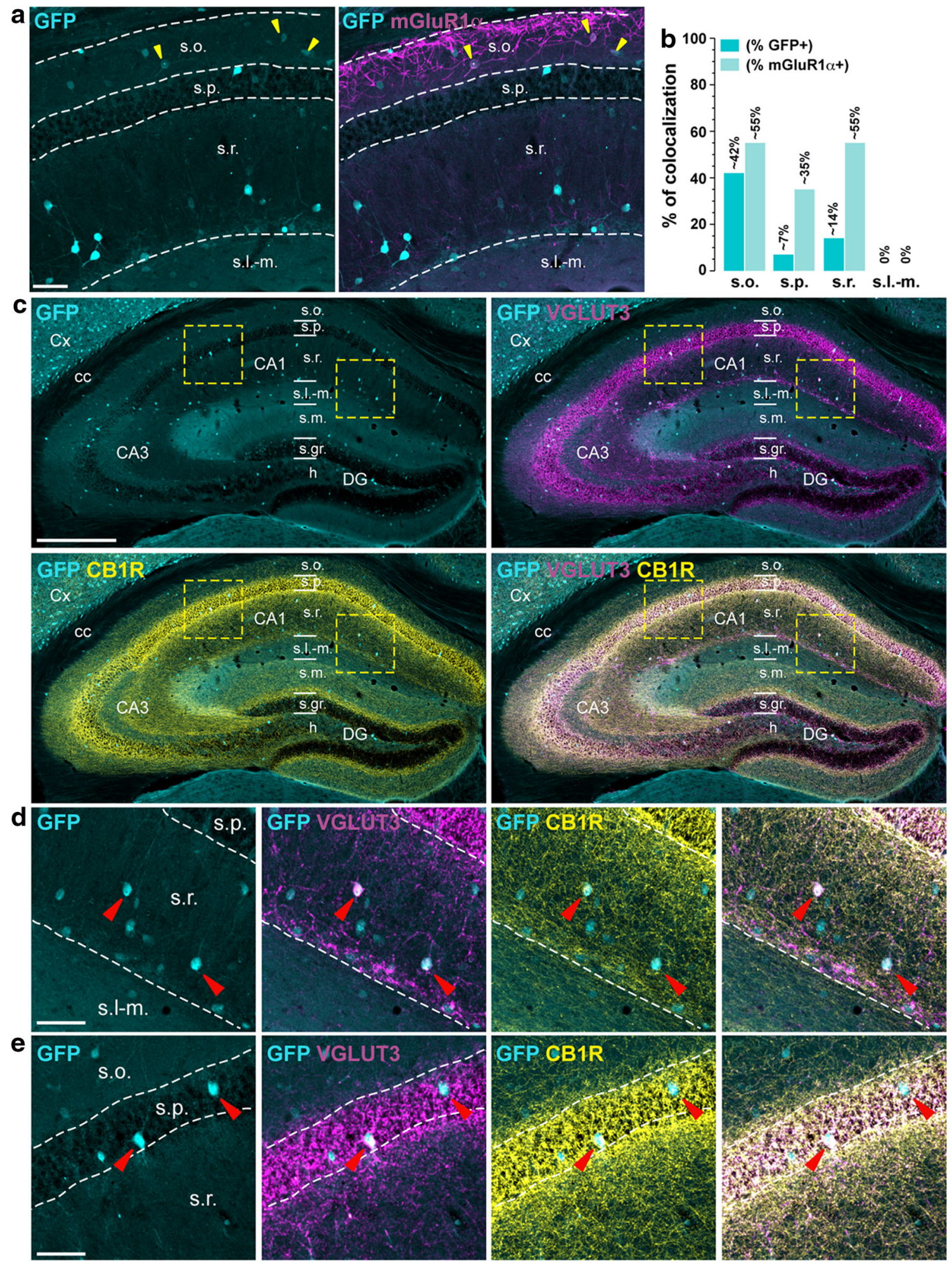

Distribution of D1R-expressing cells among miscellaneous markers

Neuronal nitric oxide synthase (nNOS). nNOS-expressing neurons represent one of the largest subclasses of interneurons present in the CA1 subfield of the hippocampus. Highly concentrated in strata oriens and lacunosum-moleculare, they allow the identification of neurogliaform and ivy interneurons (Armstrong et al. 2012; Price et al. 2005; Tricoire et al. 2010). As shown in Fig. 3, 
percentages of nNOS/GFP-immunoreactive cells were high in all the CA1 layers reaching $\sim 62$ and $\sim 57 \%$ in strata pyramidale and radiatum, and being slightly lower in strata oriens and lacunosum-moleculare $\quad(\sim 51$ and $\sim 47 \%$, respectively) (Fig. 3a, b; Table 2).

Reelin $(R L N)$. In CA1 subfield, RLN allows the identification of both glutamatergic and GABAergic interneurons (Wheeler et al. 2015). Our analysis revealed that GFP was never found in small RLN-positive cells located at the border of strata radiatum/lacunosum-moleculare, which correspond to glutamatergic Cajal-Retzius cells. In contrast, a high level of co-localization was found in strata oriens $(\sim 57 \%)$, radiatum $(\sim 64 \%)$, and lacunosummoleculare $(\sim 45 \%)$ where RLN identified O-LM and neurogliaform interneurons (Fig. 3c, d; Table 2). In stratum pyramidale, RLN-immunoreactive cells represented only $\sim 12 \%$ of GFP-expressing neurons (Fig. 3d; Table 2).

\section{Distribution of D1R-expressing cells among receptors/transporters}

Metabotropic glutamate receptor type $1 \alpha(m G l u R l \alpha)$. The largest density of mGluR1 $\alpha$-positive cells was found in stratum oriens (Tricoire et al. 2011). Within this layer, mGluR1 $\alpha$ marked preferentially trilaminar, recurrent O-LM, and O-LM interneurons and co-expressed within GFP in $\sim 42 \%$ of the case (Fig. 4a, b; Table 2). mGluR1 $\alpha /$ GFP-expressing cells were also found to a lesser extent in stratum radiatum $(\sim 14 \%)$, where they identify hippocampo-subicular projecting $\mathrm{ENK}^{+}$interneurons (Fig. 4a, b; Table 2). Low ( $7 \%$ ) and no co-localization were detected in strata pyramidale and lacunosum-moleculare, respectively (Fig. 4a, b; Table 2).

Cannabinoid type 1 receptor $(C B 1 R)$. CA1 CB1R-expressing interneurons are preferentially found in strata radiatum and lacunosum-moleculare identifying LMR projecting, Schaffer collateral-associated, and trilaminar interneurons. They also correspond to CCK-positive basket cells distributed in strata oriens, pyramidale, and radiatum (Freund and Buzsaki 1996) (Fig. 4c). Because CB1R are mainly presynaptically expressed, hippocampal CB1R immunoreactivity did not allow us to quantify the percentage of CB1R-positive cells among the D1R-expressing population. However, a few scattered CB1R/GFP-positive cells were clearly identified in stratum radiatum and at the border of strata radiatum/lacunosum-moleculare (Fig. 4d) as well as in stratum pyramidale (Fig. 4e).

Vesicular glutamate transporter type 3 (VGLUT3). Only four different types of interneurons located in strata oriens, pyramidale, and radiatum express VGLUT3 (Wheeler et al. 2015). Among them, two classes of VGLUT3-expressing interneurons are also CB1R-positive. These include CCK-positive basket and radial trilaminar interneurons. The two other subtypes are negative for CB1R and identify perforant path-associated QuaD and horizontal basket interneurons. As shown in Fig. 4, a dense plexus of VGLUT3-immunoreactive fibers surrounding the stratum pyramidale was detected in the CA1 subfield. Interestingly, most of the sparse VGLUT3/GFP-positive cells detected in strata radiatum and pyramidale were also positive for CB1R (Fig. 4c-e).

\section{CA1 D1R-positive cells express dopamine D2 receptors}

The present analysis of the distribution of GFP in DrdlaEGFP mice suggests that diverse classes of GABAergic interneurons express D1R. Because the distribution of D1R-expressing cells was reminiscent to the one recently described for CA1 D2R-containing neurons (Puighermanal et al. 2015), we analyzed whether GFP/D2R co-expressing cells were present in the CA1 dorsal hippocampus of Drdla-EGFP. The analysis of endogenous D2R distribution, using anti-D2R antibody (see Table 1), revealed a pattern of expression of D2R-positive cells that resembles to the one recently described (Puighermanal et al. 2015). Indeed, in the dentate gyrus most of the D2R-positive neurons were located in the hilus identifying the hilar mossy cells (Fig. 5a). In the CA1 subfield, D2R-labeled cells were predominantly detected in strata oriens and radiatum (Fig. 5a). In addition, an intense D2R immunoreactivity was detected in stratum lacunosummoleculare most likely corresponding to the terminals of O-LMs interneurons (Fig. 5a). On the other hand, they were rarely found in stratum pyramidale (Fig. 5a). The pattern of distribution of endogenous D2R-expressing cells was further confirmed by analyzing the degree of co-localization between D2R and HA immunoreactivity in Drd2-Cre::RiboTag mice. As illustrated, all HA-expressing cells located in strata oriens, radiatum, and at the border of strata radiatum/lacunosum-moleculare were also positive for D2R (Fig. 5b, yellow arrows). Only a few neurons were $\mathrm{D} 2 \mathrm{R}^{+} / \mathrm{HA}^{-}$suggesting that the expression of endogenous D2R might not be fully recapitulated in $\operatorname{Drd2}$ Cre::RiboTag mice (Fig. 5b).

We next examined the degree of co-localization of GFPlabeled cells with D2R in the dorsal CA1 hippocampus of Drdla-EGFP. In stratum oriens a large majority of GFPexpressing cells were also D2R positive $(\sim 82 \%)$. The percentage of GFP/D2R-immunoreactive neurons was also high in strata pyramidale and radiatum, reaching $\sim 64$ and $\sim 68 \%$, respectively (Fig. 5c, d; Table 2). By contrast, in stratum lacunosum-moleculare only 15 GFP/D2R-positive cells have been detected among the 110 GFP-immunoreactive cells (Fig. 5c, d; Table 2). 


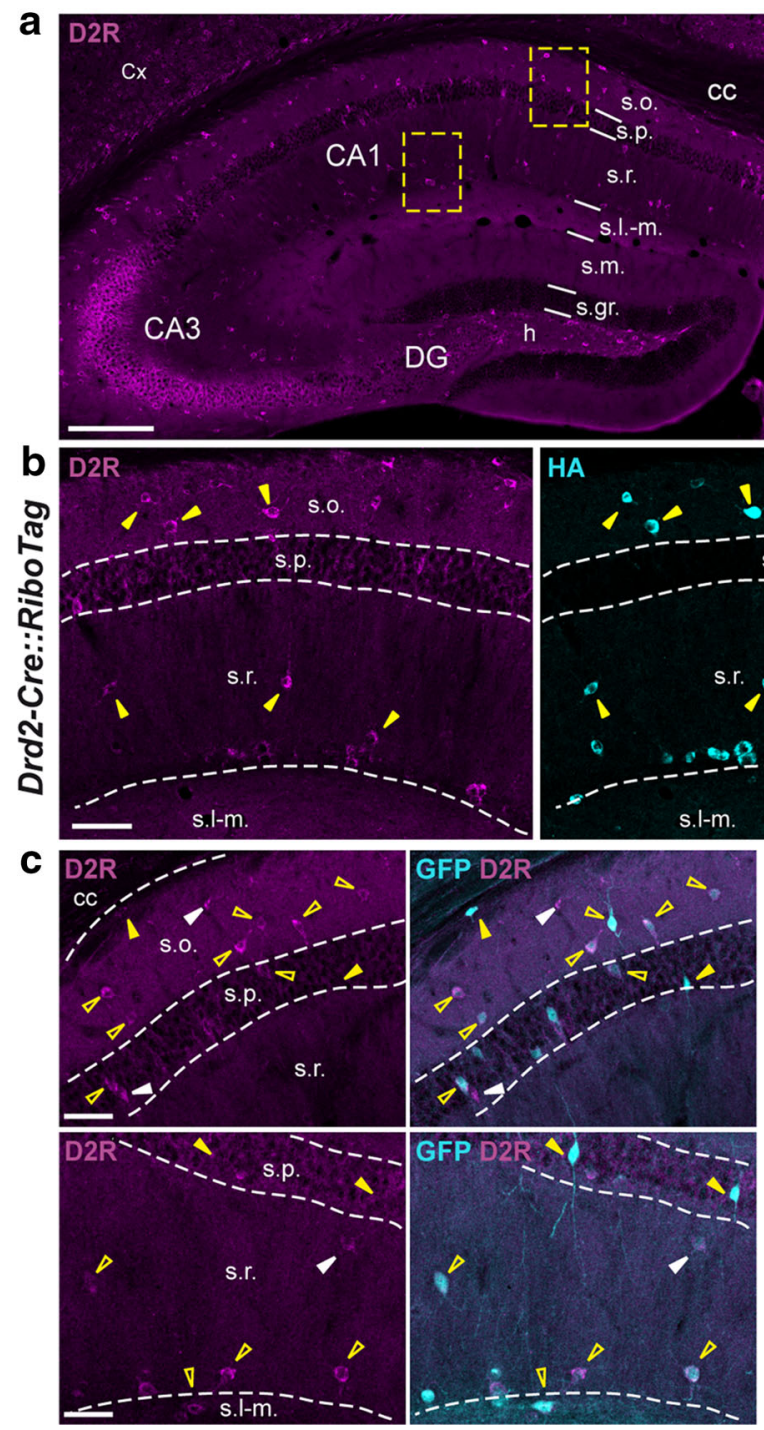

Fig. 5 Dopamine D2R-positive neurons in the CA1 dorsal hippocampus of Drdla-EGFP mice. a $\mathrm{D} 2 \mathrm{R}$ immunofluorescence in the dorsal hippocampus of Drdla-EGFP mice. High magnification images of areas delineated by the yellow stippled squares in CA1 subfield. Scale bars 400 and $20 \mu \mathrm{m}$. b HA (cyan) and D2R (magenta) immunofluorescence in the dorsal hippocampus in Drd2-Cre::RiboTag mice. Yellow arrowheads indicate HA/D2R-positive neurons in the CA1 subfield. Note that all HA-expressing cells are also D2Rpositive. Scale bar $60 \mu \mathrm{m}$. c GFP (cyan) and D2R (magenta)

To further confirm that both receptors were expressed at least by a fraction of hippocampal cells, we took advantage of the Drd2-Cre::RiboTag mice that express tagged-ribosomes selectively in D2R-containing cells (Fig. 6a). After homogenization of the hippocampus, tagged-ribosomes and their bound mRNAs were captured by HA immunoprecipitation (Fig. 6a). The analysis by quantitative RTPCR (qRT-PCR) of purified mRNAs compared to the input fraction revealed a de-enrichment of glial markers, including Gfap for astrocytes, Cnpl for oligodendrocytes, and Ibal for microglia as well as of glutamatergic
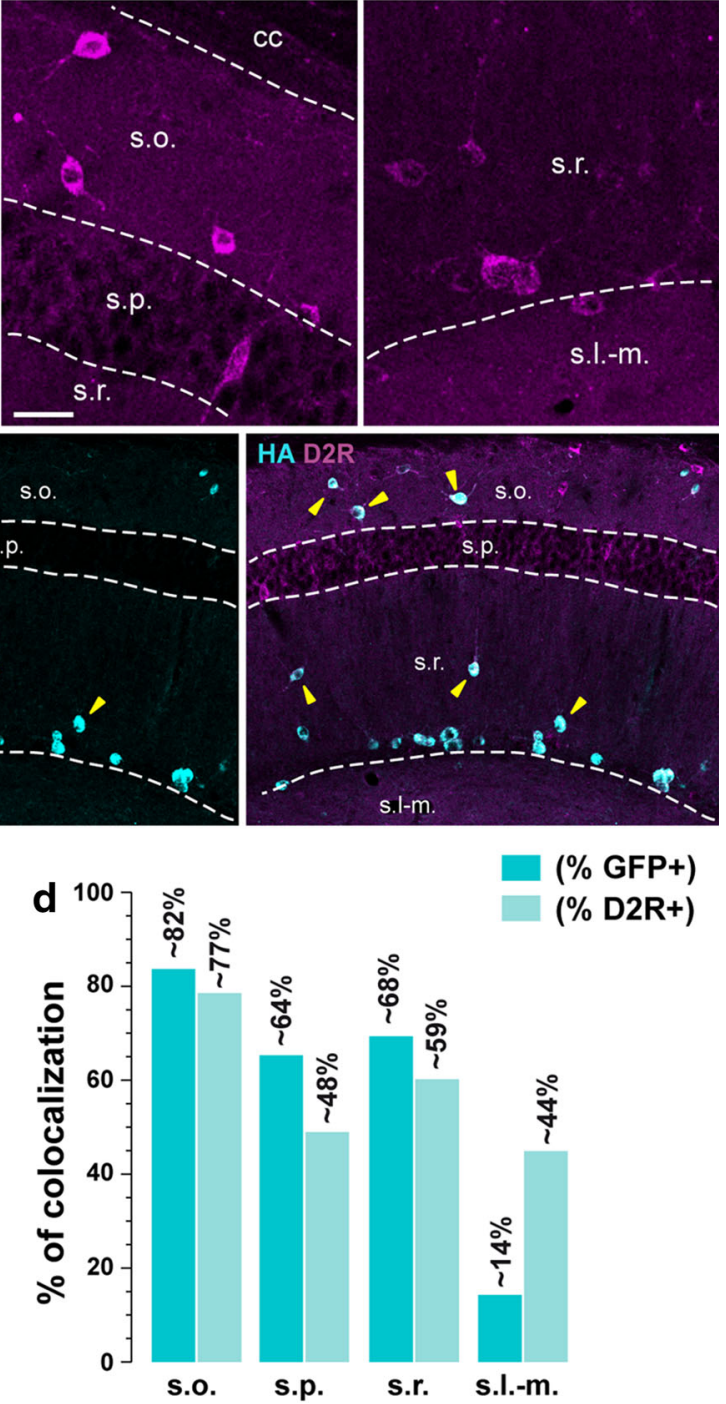

(\% GFP+)

(\% D2R+)
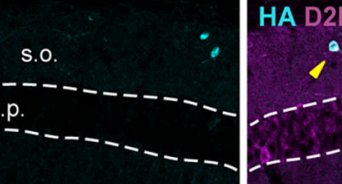

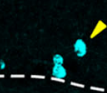

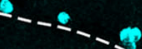

$+$

s.o. s.p. s.r. s.I.-m.

immunofluorescence in the dorsal hippocampus of Drdla-EGFP mice. Yellow open arrowheads indicate GFP/D2R-positive neurons, yellow arrowheads indicate GFP-expressing cells, and white arrowheads indicate D2R-positive neurons. Scale bar $60 \mu \mathrm{m}$. d Histograms showing the co-expression as percentage of GFP-positive cells (darkened color) and as percentage of cells expressing D2R (lightened color). Numbers of $\mathrm{GFP}^{+}$and $\mathrm{D}^{2} \mathrm{R}^{+}$cells counted are reported in Table 2 ( 4 hemispheres per mouse, 3 mice)

pyramidal cells markers such as Camk2a and Slclal (EAAT3) (Fig. 6b). By contrast, the glutamatergic CajalRetzius and hilar mossy cells marker Calb2 (CR) was highly enriched in mRNAs purified following HA immunoprecipitation (Fig. 6b). Similarly, GABAergic markers including Gad1, Slc32al (VIAAT), and Sst (SOM) were also clearly enriched (Fig. 6b) confirming our previous observations (Puighermanal et al. 2015). Finally, the presence of $\operatorname{Drd} 2$ mRNA was confirmed as expected, but also Drdla mRNAs were isolated following HA immunoprecipitation (Fig. 6c), in agreement with the co- 
Table 2 Number of cells quantified in the dorsal CA1 mouse hippocampus

\begin{tabular}{|c|c|c|c|c|c|}
\hline Figures & $\mathrm{GFP} /$ markers & s.o. & s.p. & s.r. & s.l-m \\
\hline \multirow[t]{3}{*}{ Figure $1 \mathrm{~b}$} & GFP & 411 & 288 & 421 & 145 \\
\hline & PV & 271 & 400 & 37 & 5 \\
\hline & GFP/PV & 153 & 89 & 9 & 0 \\
\hline \multirow[t]{3}{*}{ Figure $1 \mathrm{~d}$} & GFP & 372 & 272 & 421 & 139 \\
\hline & $\mathrm{CB}$ & 217 & ND & 177 & 35 \\
\hline & GFP/CB & 82 & 55 & 84 & 18 \\
\hline \multirow[t]{3}{*}{ Figure 1f } & GFP & 428 & 286 & 476 & 173 \\
\hline & $\mathrm{CR}$ & 76 & 144 & 154 & 261 \\
\hline & GFP/CR & 16 & 31 & 25 & 3 \\
\hline \multirow[t]{3}{*}{ Figure $2 b$} & GFP & 469 & 294 & 564 & 208 \\
\hline & NPY & 297 & 171 & 223 & 104 \\
\hline & GFP/NPY & 188 & 111 & 174 & 58 \\
\hline \multirow[t]{3}{*}{ Figure $2 d$} & GFP & 401 & 216 & 396 & 138 \\
\hline & SOM & 351 & 21 & 17 & 0 \\
\hline & GFP/SOM & 136 & 12 & 9 & 0 \\
\hline \multirow[t]{3}{*}{ Figure $3 b$} & GFP & 214 & 141 & 244 & 94 \\
\hline & nNOS & 141 & 123 & 206 & 71 \\
\hline & GFP/nNOS & 110 & 88 & 139 & 44 \\
\hline \multirow[t]{3}{*}{ Figure $3 d$} & GFP & 212 & 123 & 137 & 65 \\
\hline & RLN & 229 & 33 & 235 & 359 \\
\hline & GFP/RLN & 120 & 15 & 87 & 29 \\
\hline \multirow[t]{3}{*}{ Figure $4 \mathrm{~b}$} & GFP & 353 & 229 & 371 & 68 \\
\hline & mGluR1 $\alpha$ & 271 & 43 & 95 & 0 \\
\hline & GFP/mGluR1 $\alpha$ & 149 & 15 & 52 & 0 \\
\hline \multirow[t]{3}{*}{ Figure $5 \mathrm{~d}$} & GFP & 220 & 108 & 216 & 110 \\
\hline & $\mathrm{D} 2 \mathrm{R}$ & 236 & 143 & 247 & 34 \\
\hline & GFP/D2R & 181 & 69 & 146 & 15 \\
\hline
\end{tabular}

$G F P$ green fluorescent protein, $P V$ parvalbumin, $C B$ calbindin-D28k, $C R$ calretinin, $N P Y$ neuropeptide Y, $S O M$ somatostatin, $n N O S$ neuronal nitric oxide synthase, $R L N$ reelin, $m G l u R l \alpha$ metabotropic glutamate receptor type $1 \alpha, D 2 R$ dopamine D2 receptor, $N D$ not determined

localization of GFP and $D 2 R$ in Drdla-EGFP mice (Fig. 5). Taken together, these results indicate that in CA1 subfield a large proportion of D1R-expressing cells also contain D2R.

\section{Discussion}

Although the mesohippocampal DA pathway has been characterized almost three decades ago (Gasbarri et al. 1994a, b; Swanson 1982), the mechanisms by which DA mediates its effect in the hippocampus remain largely unknown. The precise characterization of hippocampal cells expressing DA receptors is therefore a critical step to understand the functional consequences of DA transmission within the hippocampus. By using BAC transgenic
Table 3 Sequences of PCR primers

\begin{tabular}{|c|c|}
\hline Marker & PCR primers \\
\hline Gfap & $\begin{array}{l}\text { Sense, AGCGAGCGTGCAGAGATGA } \\
\text { Antisense, AGGAAGCGGACCTTCTCGAT }\end{array}$ \\
\hline Cnpl & $\begin{array}{l}\text { Sense, GCTGCACTGTACAACCAAATTCTG } \\
\text { Antisense, ACCTCCTGCTGGGCGTATT }\end{array}$ \\
\hline Ibal & $\begin{array}{l}\text { Sense, CCCCCAGCCAAGAAAGCTAT } \\
\text { Antisense, GCCCCACCGTGTGACATC }\end{array}$ \\
\hline Camk2a & $\begin{array}{l}\text { Sense, TTTGAGGAACTGGGAAAGGG } \\
\text { Antisense, CATGGAGTCGGACGATATTGG }\end{array}$ \\
\hline Slcla1 & $\begin{array}{l}\text { Sense, AAAGATAGCAGGAAGGTAACCGAAT } \\
\text { Antisense, CGGTCAGTCGGTAGCTTTCAG }\end{array}$ \\
\hline Calb2 & $\begin{array}{l}\text { Sense, TGAGAATGAACTGGACGCCCTC } \\
\text { Antisense, GTAGAGCTTCCCTGCCTCGG }\end{array}$ \\
\hline Gadl & $\begin{array}{l}\text { Sense, TTGTGCTTTGCTGTGTTTTAGAGA } \\
\text { Antisense, CCCCCTGCCCAAAGATAGAC }\end{array}$ \\
\hline Sst & $\begin{array}{l}\text { Sense, CTGTCCTGCCGTCTCCAGTG } \\
\text { Antisense, CTCTGTCTGGTTGGGCTCGG }\end{array}$ \\
\hline Slc32al & $\begin{array}{l}\text { Sense, TCACGACAAACCCAAGATCAC } \\
\text { Antisense, GTCTTCGTTCTCCTCGTACAG }\end{array}$ \\
\hline $\operatorname{Drd} 2$ & $\begin{array}{l}\text { Sense, CTCTTTGGACTCAACAACACAGA } \\
\text { Antisense, AAGGGCACGTAGAACGAGAC }\end{array}$ \\
\hline Drdla & $\begin{array}{l}\text { Sense, TCGAACTGTATGGTGCCCTT } \\
\text { Antisense, TGGGGTTCAGGGAGGAATTC }\end{array}$ \\
\hline
\end{tabular}

mice expressing EGFP under the control of the D1R promoter, the present study examined the laminar distribution and determined the molecular identity of CA1 D1R-containing cells in the dorsal hippocampus. As initially reported, GFP-labeled neurons were found in all CA1 layers and were essentially GABAergic interneurons (Gangarossa et al. 2012). Our analysis revealed that GFPpositive cells were co-immunolabeled with several neurochemical markers, suggesting that various classes of GABAergic interneurons expressed D1R (Wheeler et al. 2015). Finally, we provide evidence that a large proportion of D1R-expressing neurons located in all CA1 layers also express D2R.

\section{Anatomical distribution of DA projections and expression pattern of D1R-expressing cells}

An early tract-tracing study and double immunofluorescence analyses reported that VTA DA neurons projecting to the hippocampus were preferentially localized in strata oriens and pyramidale, with sparse fibers in stratum radiatum and barely any innervation of stratum lacunosummoleculare (Gasbarri et al. 1994a, b; Kwon et al. 2008). This heterogeneous laminar distribution of DA fibers within CA1 was recently confirmed by analyzing hippocampal efferents from genetically defined VTA DA 
a
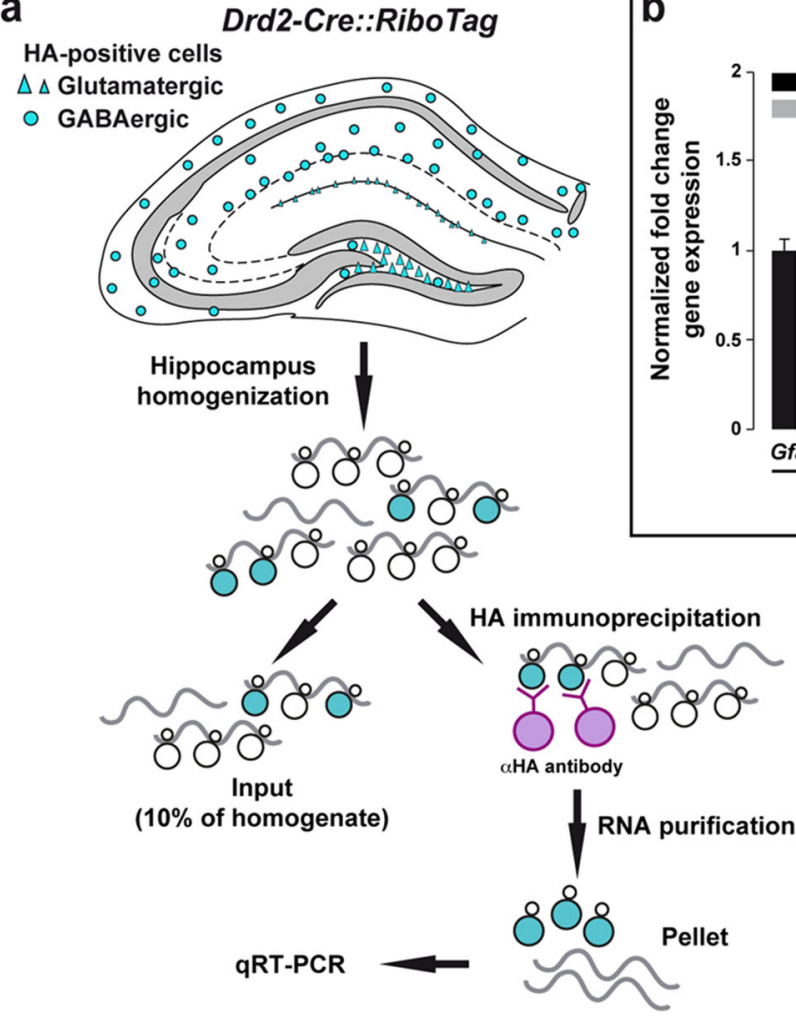
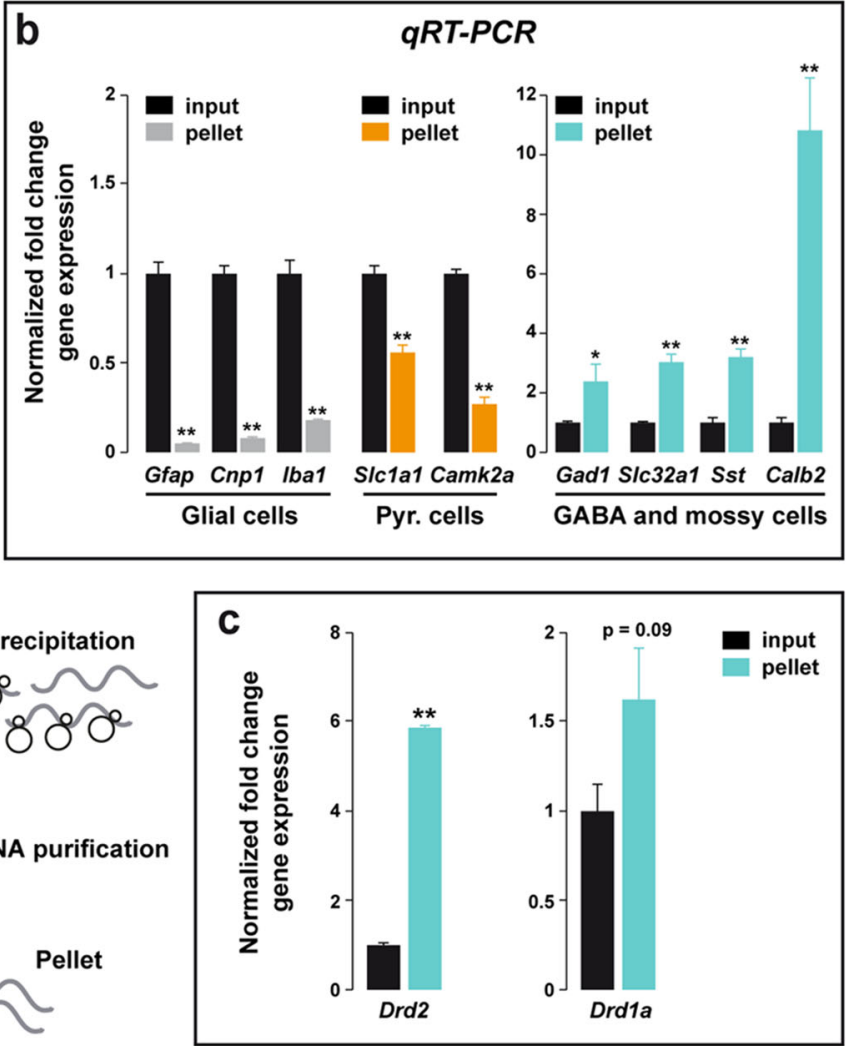

Fig. 6 D2R-expressing cells are enriched in Drd1 mRNA. a D2Rexpressing cells, either glutamatergic (triangles) or GABAergic (circles), contain ribosomes tagged with the HA epitope in Drd2Cre::RiboTag mice. After hippocampus homogenization, $10 \%$ of the lysate was saved as input fraction (containing all mRNAs), while the mRNAs bound to tagged-ribosomes were isolated through HAimmunoprecipitation (pellet fraction). b Quantitative RT-PCR analysis of mRNAs isolated following HA immunoprecipitation from hippocampi of Drd2-Cre::RiboTag mice. All genes were normalized to $\beta$-actin. Data are expressed as the fold change comparing the pellet

neurons using Cre-inducible AAV-expressing ChR2-EYFP (Broussard et al. 2016; McNamara et al. 2014; Rosen et al. 2015). Interestingly, our analysis revealed that D1R-expressing cells are found in a large proportion in stratum oriens and to a lesser extent in stratum pyramidale. Thus, in these two layers DA terminals largely overlap with D1Rcontaining neurons as illustrated by the presence of GFPlabeled neurons in the vicinity of TH-positive fibers (Supplemental Figure 1, Inset). D1R-expressing cells are also present in strata radiatum and at the border of $\mathrm{ra}$ diatum/lacunosum-moleculare. However, despite the detection of TH immunoreactivity (Supplemental Figure 1), VTA DA neurons do not innervate these two layers (Broussard et al. 2016; McNamara et al. 2014; Rosen et al. 2015). In fact, strong evidence indicate that the dense plexus of TH-labeled fibers observed within strata radiatum and lacunosum-moleculare corresponds to noradrenergic (NE) axons arising from the locus coeruleus (LC) fraction versus the input. Negative control genes, including glial markers (Gfap, Cnp and Ibal; grey bars) and pyramidal cell markers (Slcla1 and Camk2a; orange bars) were de-enriched in the pellet samples, whereas the positive control genes including GABAergic and mossy cell markers (Gad1, Slc32a1, Sst and Calb2; cyan bars) were enriched in the pellet compared to the input fraction. c Quantitative RT-PCR analysis of Drd2 and Drd1 genes after HA immunoprecipitation from hippocampi of Drd2-Cre::RiboTag mice $(n=6$ mice). Data are analyzed by two tailed Student $t$ test. $* p<0.05, * * p<0.001$ pellet vs. input

(Kwon et al. 2008). Of interest, a recent study showed that these LC NE fibers co-release DA and NE, suggesting that they constitute the only source of DA in the vicinity of D1R-expressing neurons located in these two layers (Smith and Greene 2012; Walling et al. 2012). Therefore, depending on their laminar location, D1R-expressing neurons could be controlled by DA arising from two distinct sources: the VTA for strata oriens and pyramidale and the LC for strata radiatum and lacunosum-moleculare.

\section{Reliability of the distribution of D1R-expressing cells in Drd1a-EGFP mice}

If the expression of D1R by the granule cells in the dentate gyrus is well admitted and has been demonstrated by in situ hybridization, binding, and immunofluorescence studies (Boyson et al. 1986; Fremeau et al. 1991; Gangarossa et al. 2012; Huang et al. 1992; Mansour et al. 1990, 1991; 
Rocchetti et al. 2015; Sarinana et al. 2014), the distribution/identity of D1R-expressing cells in the CA1 subfield remains unclear. Indeed, although the presence of D1R in pyramidal cells has been suggested (Huang et al. 1992; Kern et al. 2015; Ladepeche et al. 2013a, b), little or no signal for D1R at the transcript level was detected (Fremeau et al. 1991; Mansour et al. 1990; Rocchetti et al. 2015; Sarinana et al. 2014). Consistent with these latter findings, our analysis revealed a weak and sparse distribution of GFP-labeled neurons in stratum pyramidale. This finding strongly suggests that the D1R staining detected in this layer and initially thought to label the plasma membrane of CA1 pyramidal cells (Huang et al. 1992) most likely corresponds to D1R-positive terminals arising from another cell type, possibly GABAergic interneurons. Supporting this hypothesis, D1R-expressing cells were found in strata oriens and radiatum/lacunosum-moleculare (Gangarossa et al. 2012; present study), three layers populated by a large diversity of GABAergic interneurons (Wheeler et al. 2015). The distribution of GFP-labeled cells reported in the present study is consistent with the early description of the D1R expression pattern. Thus, although at low density, autoradiography studies revealed the presence of D1R binding sites in stratum oriens (Mansour et al. 1990, 1991). Moreover, cells containing D1R mRNA have been detected in both strata oriens and radiatum (Fremeau et al. 1991). Finally, both layers also exhibit a strong D1R immunoreactivity (Huang et al. 1992). Combined with previous findings, our results strongly suggest that D1R are preferentially expressed by GABAergic interneurons and not by pyramidal cells within the CA1 subfield.

\section{D1R is expressed in various classes of GABAergic interneurons in CA1}

The use of different neurochemical markers including calcium-binding proteins (parvalbumin, calbindin-D28k, calretinin), neuropeptides (somatostatin, NPY), receptors/transporters (mGluR1 $\alpha$, CB1R, VGLUT3) and miscellaneous markers (nNOS, reelin) allowed us to evaluate the distribution of GFP among 33 out of the 37 types of interneurons known to be present in CA1 (Wheeler et al. 2015). Based on the laminar localization and the percentage of co-localization, we estimate that D1R are expressed by at least eight distinct classes of GABAergic interneurons. For instance, the high percentage of GFP/nNOSpositive cells in all layers indicate that D1R might be expressed by both ivy and neurogliaform cells (Armstrong et al. 2012; Price et al. 2005; Tricoire et al. 2010). Their presence in this latter population is further supported by the strong percentage of GFP/NPY- and GFP/reelin-positive neurons estimated in the stratum lacunosum-moleculare (Fuentealba et al. 2008; Tricoire et al. 2011). In stratum oriens, the co-expression of GFP with SOM/mGluR1 $\alpha$ suggests that D1R are expressed by O-LMs and trilaminar interneurons (Chittajallu et al. 2013; Klausberger 2009; Matyas et al. 2004; Tricoire et al. 2011). The presence of GFP/PV-expressing cells also favors the hypothesis that axo-axonic, basket, and bistratified interneurons contain D1R. This observation is further strengthened by the recent demonstration of the critical role played by D1R signaling in PV cells for the consolidation of long-term memory (Karunakaran et al. 2016). Finally, although not quantified, the presence of GFP/VGLUT3/CB1R-positive neurons suggests that basket $\mathrm{CCK}^{+}$might express D1R (Wheeler et al. 2015). Interestingly, most of the D1R-containing cells located in the stratum pyramidale correspond to GABAergic interneurons. Based on the combination of the molecular marker they express, one can reasonably conclude they comprise axo-axonic, basket, bistratified, and ivy cells. Finally, a small fraction of GFP-positive neurons were co-labeled with calbindin-D28k, confirming the scarity of pyramidal neurons expressing D1R. Our cross analysis also allowed us to identify CA1 cell types devoid of D1R. Thus, at least two types of interneurons, the perforant path-associated QuaD located in stratum radiatum and the quadrilaminar interneurons found in both strata radiatum and lacunosum-moleculare (Pawelzik et al. 2002; Tricoire et al. 2011). Finally, the lack of co-localization between GFP and calretinin/reelin-positive cells localized in stratum lacunosum-moleculare supports the absence of D1R in Cajal-Retzius cells (Marchionni et al. 2010; Tricoire et al. 2011). Further experiments using double fluorescent in situ hybridization and/or cell-type specific mRNA profiling should help to further confirm the presence of D1R transcripts in these distinct classes of GABAergic interneurons.

\section{Evidence for D1R and D2R co-expression in CA1 GABAergic interneurons}

Although BAC transgenic mice expressing fluorescent proteins represent a useful tool to characterize genetically identified cell populations, caution should be taken when analyzing the expression pattern. Indeed, during the course of the characterization of our Drd2-Cre::RiboTag mouse line, which express tagged-ribosomes selectively in D2R-containing cells, we found that in the hippocampus D2R-expressing cells displayed a much widespread pattern than the one initially described in Drd2-EGFP mice (Gangarossa et al. 2012; Puighermanal et al. 2015). The difference was particularly evident in CA1 where HApositive cells of Drd2-Cre::RiboTag mice identified diverse classes of GABAergic interneurons (Gangarossa et al. 2012; Puighermanal et al. 2015). This observation, together with our present analysis, led us to re-examine 
whether, in the CA1 subfield, D1R and D2R-expressing cells were fully segregated, as initially thought (Gangarossa et al. 2012; Puighermanal et al. 2015), or could partially overlap. The present findings argue in favor of this last hypothesis. Thus, in strata oriens, pyramidale, and radiatum, our double immunofluorescence analysis revealed a high degree of co-localization between GFP and D2R. The presence of cells co-expressing both D1R and D2R was further confirmed by the enrichment of Drd1 transcripts isolated from tagged-ribosomes expressed in D2R-containing cells. Interestingly, the presence of both receptors on diverse GABAergic interneurons, which for some of them have antagonistic activity onto CA1 pyramidal cells, could account for the complexity and variability of DA action following bath application in hippocampal slices. Indeed, while DA bath application does affect excitatory Schaffer collateral (SC) drive onto CA1 pyramidal cells, a depression of the synaptic transmission of temporoammonic (TA) pathway has been reported (Ito and Schuman 2007; Otmakhova and Lisman 1999). This latter effect, which requires both D1R and D2R, also involves local GABAergic interneurons located at the border of strata radiatum and lacunosum-moleculare (Ito and Schuman 2007; Otmakhova and Lisman 1999). However, at this synapse, following high-frequency stimulation, DA facilitates excitatory drive to CA1 pyramidal cells mainly through the decreased feedforward inhibition (Ito and Schuman 2007; Otmakhova and Lisman 1999). Therefore, one can envision that the ability of DA to gate TA synaptic transmission would not only depend on the excitatory inputs frequency but also depend on the dual action of DA on GABAergic interneurons co-expressing both D1R and D2R. Because these different types of D1R/D2R-expressing interneurons innervate specific and distinct domains of pyramidal cells and other interneurons, future experiments will be necessary to understand whether their pattern of activity will change depending on tonic, phasic, or ramping DA signals.

In conclusion, our study revealed that in the CA1 subfield of the hippocampus, distinct classes of GABAergic interneurons express D1R. Contrasting with the dorsal striatum where D1R and D2R are highly segregated (Bertran-Gonzalez et al. 2010; Valjent et al. 2009), a high degree of D1R-containing neurons also express D2R. Future studies using cell-type specific invalidation of D1R and/or D2R are promptly required to untangle the complexity of DA signals within the hippocampus.

Acknowledgments This work was supported by Inserm, Fondation pour la Recherche Médicale (EV), and a NARSAD Young Investigator Grant from the Brain and Behavior Research Foundation (EP). $\mathrm{EP}$ is a recipient of Marie Curie Intra-European Fellowship IEF327648. LC is a recipient of LABEX EpiGenMed Fellowship.
Open Access This article is distributed under the terms of the Creative Commons Attribution 4.0 International License (http://crea tivecommons.org/licenses/by/4.0/), which permits unrestricted use, distribution, and reproduction in any medium, provided you give appropriate credit to the original author(s) and the source, provide a link to the Creative Commons license, and indicate if changes were made.

\section{References}

Armstrong C, Krook-Magnuson E, Soltesz I (2012) Neurogliaform and ivy cells: a major family of nNOS expressing GABAergic neurons. Front Neural Circuits 6:23

Bertran-Gonzalez J, Bosch C, Maroteaux M, Matamales M, Herve D, Valjent E, Girault JA (2008) Opposing patterns of signaling activation in dopamine D1 and D2 receptor-expressing striatal neurons in response to cocaine and haloperidol. $\mathrm{J}$ Neurosci 28(22):5671-5685

Bertran-Gonzalez J, Hervé D, Girault JA, Valjent E (2010) What is the degree of segregation between striatonigral and striatopallidal projections? Front Neuroanat 4. doi:10.3389/fnana.2010. 00136

Bethus I, Tse D, Morris RG (2010) Dopamine and memory: modulation of the persistence of memory for novel hippocampal NMDA receptor-dependent paired associates. J Neurosci 30(5):1610-1618

Boyson SJ, McGonigle P, Molinoff PB (1986) Quantitative autoradiographic localization of the D1 and D2 subtypes of dopamine receptors in rat brain. J Neurosci 6(11):3177-3188

Bromberg-Martin ES, Matsumoto M, Hikosaka O (2010) Dopamine in motivational control: rewarding, aversive, and alerting. Neuron 68(5):815-834

Broussard JI, Yang K, Levine AT, Tsetsenis T, Jenson D, Cao F, Garcia I, Arenkiel BR, Zhou FM, De Biasi M et al (2016) Dopamine regulates aversive contextual learning and associated in vivo synaptic plasticity in the hippocampus. Cell Rep 14(8):1930-1939

Chittajallu R, Craig MT, McFarland A, Yuan X, Gerfen S, Tricoire L, Erkkila B, Barron SC, Lopez CM, Liang BJ et al (2013) Dual origins of functionally distinct O-LM interneurons revealed by differential 5-HT(3A)R expression. Nat Neurosci 16(11):1598-1607

Franklin K, Paxinos G (2007) The mouse brain in stereotaxic coordinates, 3rd edn. Elsevier, Amsterdam

Fremeau RT Jr, Duncan GE, Fornaretto MG, Dearry A, Gingrich JA, Breese GR, Caron MG (1991) Localization of D1 dopamine receptor mRNA in brain supports a role in cognitive, affective, and neuroendocrine aspects of dopaminergic neurotransmission. Proc Natl Acad Sci USA 88(9):3772-3776

Freund TF, Buzsaki G (1996) Interneurons of the hippocampus. Hippocampus 6(4):347-470

Fuentealba P, Begum R, Capogna M, Jinno S, Marton LF, Csicsvari J, Thomson A, Somogyi P, Klausberger T (2008) Ivy cells: a population of nitric-oxide-producing, slow-spiking GABAergic neurons and their involvement in hippocampal network activity. Neuron 57(6):917-929

Furini CR, Myskiw JC, Schmidt BE, Marcondes LA, Izquierdo I (2014) D1 and D5 dopamine receptors participate on the consolidation of two different memories. Behav Brain Res 271:212-217

Gangarossa G, Longueville S, De Bundel D, Perroy J, Herve D, Girault JA, Valjent E (2012) Characterization of dopamine D1 and D2 receptor-expressing neurons in the mouse hippocampus. Hippocampus 22(12):2199-2207 
Gasbarri A, Packard MG, Campana E, Pacitti C (1994a) Anterograde and retrograde tracing of projections from the ventral tegmental area to the hippocampal formation in the rat. Brain Res Bull 33(4):445-452

Gasbarri A, Verney C, Innocenzi R, Campana E, Pacitti C (1994b) Mesolimbic dopaminergic neurons innervating the hippocampal formation in the rat: a combined retrograde tracing and immunohistochemical study. Brain Res 668(1-2):71-79

Gasbarri A, Sulli A, Packard MG (1997) The dopaminergic mesencephalic projections to the hippocampal formation in the rat. Prog Neuropsychopharmacol Biol Psychiatry 21(1):1-22

Gong S, Zheng C, Doughty ML, Losos K, Didkovsky N, Schambra UB, Nowak NJ, Joyner A, Leblanc G, Hatten ME et al (2003) A gene expression atlas of the central nervous system based on bacterial artificial chromosomes. Nature 425(6961):917-925

Heath FC, Jurkus R, Bast T, Pezze MA, Lee JL, Voigt JP, Stevenson CW (2015) Dopamine D1-like receptor signalling in the hippocampus and amygdala modulates the acquisition of contextual fear conditioning. Psychopharmacology 232(14):2619-2629

Horvitz JC, Stewart T, Jacobs BL (1997) Burst activity of ventral tegmental dopamine neurons is elicited by sensory stimuli in the awake cat. Brain Res 759(2):251-258

Huang Q, Zhou D, Chase K, Gusella JF, Aronin N, DiFiglia M (1992) Immunohistochemical localization of the D1 dopamine receptor in rat brain reveals its axonal transport, pre- and postsynaptic localization, and prevalence in the basal ganglia, limbic system, and thalamic reticular nucleus. Proc Natl Acad Sci USA 89(24):11988-11992

Ito HT, Schuman EM (2007) Frequency-dependent gating of synaptic transmission and plasticity by dopamine. Front Neural Circuits $1: 1$

Jinno S, Kosaka T (2002) Patterns of expression of calcium binding proteins and neuronal nitric oxide synthase in different populations of hippocampal GABAergic neurons in mice. J Comp Neurol 449(1):1-25

Karunakaran S, Chowdhury A, Donato F, Quairiaux C, Michel CM, Caroni P (2016) PV plasticity sustained through D1/5 dopamine signaling required for long-term memory consolidation. Nat Neurosci 19(3):454-464

Kern A, Mavrikaki M, Ullrich C, Albarran-Zeckler R, Brantley AF, Smith RG (2015) Hippocampal dopamine/DRD1 signaling dependent on the Ghrelin receptor. Cell 163(5):1176-1190

Klausberger T (2009) GABAergic interneurons targeting dendrites of pyramidal cells in the CA1 area of the hippocampus. Eur $\mathrm{J}$ Neurosci 30(6):947-957

Kwon OB, Paredes D, Gonzalez CM, Neddens J, Hernandez L, Vullhorst D, Buonanno A (2008) Neuregulin-1 regulates LTP at CA1 hippocampal synapses through activation of dopamine D4 receptors. Proc Natl Acad Sci USA 105(40):15587-15592

Ladepeche L, Dupuis JP, Bouchet D, Doudnikoff E, Yang L, Campagne Y, Bezard E, Hosy E, Groc L (2013a) Singlemolecule imaging of the functional crosstalk between surface NMDA and dopamine D1 receptors. Proc Natl Acad Sci USA 110(44): 18005-18010

Ladepeche L, Yang L, Bouchet D, Groc L (2013b) Regulation of dopamine D1 receptor dynamics within the postsynaptic density of hippocampal glutamate synapses. PLoS One 8(9):e74512

Lammel S, Lim BK, Ran C, Huang KW, Betley MJ, Tye KM, Deisseroth K, Malenka RC (2012) Input-specific control of reward and aversion in the ventral tegmental area. Nature 491(7423):212-217

Lemon N, Manahan-Vaughan D (2006) Dopamine D1/D5 receptors gate the acquisition of novel information through hippocampal long-term potentiation and long-term depression. J Neurosci 26(29):7723-7729
Lisman JE, Grace AA (2005) The hippocampal-VTA loop: controlling the entry of information into long-term memory. Neuron 46(5):703-713

Ljungberg T, Apicella P, Schultz W (1992) Responses of monkey dopamine neurons during learning of behavioral reactions. J Neurophysiol 67(1):145-163

Mansour A, Meador-Woodruff JH, Bunzow JR, Civelli O, Akil H, Watson SJ (1990) Localization of dopamine D2 receptor mRNA and D1 and D2 receptor binding in the rat brain and pituitary: an in situ hybridization-receptor autoradiographic analysis. J Neurosci 10(8):2587-2600

Mansour A, Meador-Woodruff JH, Zhou QY, Civelli O, Akil H, Watson SJ (1991) A comparison of D1 receptor binding and mRNA in rat brain using receptor autoradiographic and in situ hybridization techniques. Neuroscience 45(2):359-371

Marchionni I, Takacs VT, Nunzi MG, Mugnaini E, Miller RJ, Maccaferri G (2010) Distinctive properties of CXC chemokine receptor 4-expressing Cajal-Retzius cells versus GABAergic interneurons of the postnatal hippocampus. J Physiol 588( $\mathrm{Pt}$ 15):2859-2878

Matyas F, Freund TF, Gulyas AI (2004) Immunocytochemically defined interneuron populations in the hippocampus of mouse strains used in transgenic technology. Hippocampus 14(4):460-481

McNamara CG, Tejero-Cantero A, Trouche S, Campo-Urriza N, Dupret D (2014) Dopaminergic neurons promote hippocampal reactivation and spatial memory persistence. Nat Neurosci 17(12):1658-1660

Otmakhova NA, Lisman JE (1999) Dopamine selectively inhibits the direct cortical pathway to the CA1 hippocampal region. J Neurosci 19(4):1437-1445

Pawelzik H, Hughes DI, Thomson AM (2002) Physiological and morphological diversity of immunocytochemically defined parvalbumin- and cholecystokinin-positive interneurones in CA1 of the adult rat hippocampus. J Comp Neurol 443(4):346-367

Poulin JF, Zou J, Drouin-Ouellet J, Kim KY, Cicchetti F, Awatramani RB (2014) Defining midbrain dopaminergic neuron diversity by single-cell gene expression profiling. Cell Rep 9(3):930-943

Price CJ, Cauli B, Kovacs ER, Kulik A, Lambolez B, Shigemoto R, Capogna M (2005) Neurogliaform neurons form a novel inhibitory network in the hippocampal CA1 area. J Neurosci 25(29):6775-6786

Puighermanal E, Biever A, Espallergues J, Gangarossa G, De Bundel D, Valjent E (2015) drd2-cre:ribotag mouse line unravels the possible diversity of dopamine $\mathrm{d} 2$ receptor-expressing cells of the dorsal mouse hippocampus. Hippocampus 25(7):858-875

Rocchetti J, Isingrini E, Dal Bo G, Sagheby S, Menegaux A, Tronche F, Levesque D, Moquin L, Gratton A, Wong TP, Rubinstein M, Giros B (2015) Presynaptic D2 dopamine receptors control longterm depression expression and memory processes in the temporal hippocampus. Biol Psychiatry 77(6):513-525

Rosen ZB, Cheung S, Siegelbaum SA (2015) Midbrain dopamine neurons bidirectionally regulate CA3-CA1 synaptic drive. Nat Neurosci 18(12):1763-1771

Rossato JI, Bevilaqua LR, Izquierdo I, Medina JH, Cammarota M (2009) Dopamine controls persistence of long-term memory storage. Science 325(5943): 1017-1020

Sanz E, Yang L, Su T, Morris DR, McKnight GS, Amieux PS (2009) Cell-type-specific isolation of ribosome-associated mRNA from complex tissues. Proc Natl Acad Sci USA 106(33):13939-13944

Sarinana J, Kitamura T, Kunzler P, Sultzman L, Tonegawa S (2014) Differential roles of the dopamine 1-class receptors, D1R and D5R, in hippocampal dependent memory. Proc Natl Acad Sci USA 111(22):8245-8250

Schultz W (2016) Dopamine reward prediction-error signalling: a two-component response. Nat Rev Neurosci 17(3):183-195 
Smith CC, Greene RW (2012) CNS dopamine transmission mediated by noradrenergic innervation. J Neurosci 32(18):6072-6080

Swanson LW (1982) The projections of the ventral tegmental area and adjacent regions: a combined fluorescent retrograde tracer and immunofluorescence study in the rat. Brain Res Bull 9(1-6):321-353

Tricoire L, Pelkey KA, Daw MI, Sousa VH, Miyoshi G, Jeffries B, Cauli B, Fishell G, McBain CJ (2010) Common origins of hippocampal Ivy and nitric oxide synthase expressing neurogliaform cells. J Neurosci 30(6):2165-2176

Tricoire L, Pelkey KA, Erkkila BE, Jeffries BW, Yuan X, McBain CJ (2011) A blueprint for the spatiotemporal origins of mouse hippocampal interneuron diversity. J Neurosci 31(30): 10948-10970
Valjent E, Bertran-Gonzalez J, Herve D, Fisone G, Girault JA (2009) Looking BAC at striatal signaling: cell-specific analysis in new transgenic mice. Trends Neurosci 32(10):538-547

Walling SG, Brown RA, Miyasaka N, Yoshihara Y, Harley CW (2012) Selective wheat germ agglutinin (WGA) uptake in the hippocampus from the locus coeruleus of dopamine-betahydroxylase-WGA transgenic mice. Front Behav Neurosci 6:23

Wheeler DW, White CM, Rees CL, Komendantov AO, Hamilton DJ, Ascoli GA (2015) Hippocampome.org: a knowledge base of neuron types in the rodent hippocampus. Elife 4. doi:10.7554/ eLife.09960 